\title{
Situs inversus and ciliary abnormalities: 20 years later, what is the connection?
}

\author{
Petra Pennekamp ${ }^{1 *}$, Tabea Menchen ${ }^{1}$, Bernd Dworniczak ${ }^{2}$ and Hiroshi Hamada ${ }^{3}$
}

\begin{abstract}
Heterotaxy (also known as situs ambiguous) and situs inversus totalis describe disorders of laterality in which internal organs do not display their typical pattern of asymmetry. First described around 1600 by Girolamo Fabrizio, numerous case reports about laterality disorders in humans were published without any idea about the underlying cause. Then, in 1976, immotile cilia were described as the cause of a human syndrome that was previously clinically described, both in 1904 by AK Siewert and in 1933 by Manes Kartagener, as an association of situs inversus with chronic sinusitis and bronchiectasis, now commonly known as Kartagener's syndrome. Despite intense research, the underlying defect of laterality disorders remained unclear. Nearly 20 years later in 1995, Björn Afzelius discussed five hypotheses to explain the connection between ciliary defects and loss of laterality control in a paper published in the International Journal of Developmental Biology asking: 'Situs inversus and ciliary abnormalities: What is the connection?'. Here, nearly 20 research years later, we revisit some of the key findings that led to the current knowledge about the connection between situs inversus and ciliary abnormalities.
\end{abstract}

Keywords: Situs inversus, Cilia, Left-right organizer, Node, Nodal, Nodal flow, Two cilia model, Planar cell polarity, Motile cilia, Sensory cilia

\section{Review}

\section{Laterality defects in humans}

Left-right asymmetry is common in nature. Disorders of left-right asymmetry can cause randomization (heterotaxy/situs ambiguous) or complete reversal of organ position (situs inversus totalis) (reviewed in [1-3]). The first reports describing laterality defects came from Girolamo Fabrizio (Hieronymus Fabricius; 1537 to 1619; Italian anatomist and surgeon) around 1600, followed by Marco Aurelio Severino (1580 to 1656, Italian anatomist and surgeon) who first documented the finding of a human heart being on the right hand side of the body in 1643 [4], and also Matthew Baillie (1761 to 1823, Scottish physician and pathologist) who described the complete mirror image reversal of the thoracic and abdominal organs more than a century later in 1788 [5].

In the following centuries numerous case reports about laterality disorders were published. In a frequently overlooked case study published in 1904, Dr. AK

\footnotetext{
* Correspondence: Petra.Pennekamp@ukmuenster.de

'Department of General Pediatrics, University Children's Hospital Muenster, 48149 Muenster, Germany

Full list of author information is available at the end of the article
}

Siewert from Kiev (Ukraine) described a patient 'who since birth had the unusual combination of symptoms of bronchiectasis and situs inversus totalis' [6]. This was the first description of what has since become known as 'Kartagener's syndrome (KS)' based on the description by Manes Kartagener in 1933 [7], sometimes still referred to as Siewert's (Zivert's) syndrome, Siewert (Zivert)-Kartagener syndrome, or 'immotile cilia syndrome'. It was later renamed 'primary ciliary dyskinesia (PCD)' after dysmotile cilia had been observed in individuals diagnosed clinically as having KS $[8,9]$.

Although several decades of research were required to understand the connection behind laterality disorders and the role of cilia, Kartagener was already thinking in the right direction. He noted in one simple sentence that 'cystic kidneys, which are often compared with congenital bronchiectasis, have been observed in combination with situs inversus' $[7,10]$. At that time nobody was aware that two types of cilia would be involved in laterality development and that genes causing cystic kidney disease would also play a role [11].

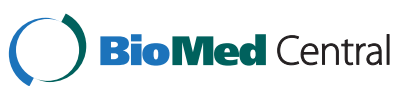

(c) 2015 Pennekamp et al.; licensee BioMed Central. This is an Open Access article distributed under the terms of the Creative Commons Attribution License (http://creativecommons.org/licenses/by/4.0), which permits unrestricted use, distribution, and reproduction in any medium, provided the original work is properly credited. The Creative Commons Public Domain Dedication waiver (http://creativecommons.org/publicdomain/zero/1.0/) applies to the data made available in this article, unless otherwise stated. 


\section{Structural defects of cilia as the cause for Kartagener's syndrome}

Numerous case reports about laterality defects in humans were published in the following years, but still lacked any direct correlation between laterality disorders and cilia function. During that time, Björn Afzelius had improved sample preparation for electron microscopy, leading to a better preservation and analysis of ciliary ultrastructure [12]. Years later in 1974, Afzelius met Henning Pedersen, who showed Afzelius his unpublished electron micrograph of an immotile human sperm tail lacking dynein arms. Afzelius suggested that Pedersen publish these findings soon. After meeting Pedersen, Afzelius analyzed - together with Rune Eliasson - sperm samples from male patients with stiff, immotile sperm tails. As expected, they also found lack of dynein arms as the cause for immotile human spermatozoa in these patients. Pedersen and Afzelius subsequently published their findings nearly at the same time in 1975 [13-15].

Following these landmark studies, the hypothesis was raised that $\mathrm{KS}$ is caused by a genetic lack of dynein arms in cilia [16]. Both Afzelius and Pedersen proved independently that dynein arms were missing in cilia of nasal and bronchial mucosa of affected patients, confirming this hypothesis $[17,18]$. Afzelius sent a letter to Kartagener to notify him about these findings, but Kartagener's daughter reported to Afzelius that he had died in August 1975. Evidently this information was never brought to Kartagener's attention $[15,19]$.

\section{Special type of cilia at the embryonic organizer}

Although the ultrastructural defect causing ciliary immotility and bronchiectasis in patients with KS was identified, the connection between ciliary immotility and body axis development remained elusive. Afzelius early on raised the hypothesis that motile cilia defects can explain a variety of phenotypes/defects observed in patients with $\mathrm{KS}$, but not all. He also discussed the existence of 'so-called sensory hairs protruding from the cell surface into the extracellular space' to explain the poor sense of smell and decreased hearing ability in these patients [17]. To explain the connection between cilia and the situs inversus observed in patients with KS, Afzelius also mentioned that 'a further category of cells which carry cilia is the differentiating cells of vertebrate embryos', referring to a publication analyzing cilia during cardiac development of the chicken [20]. He hypothesized that it is not unreasonable to assume that a malrotation may occur when the ciliary movement causing rotation is lacking' and that 'chance alone will determine whether the viscera will take up the normal or the reversed position during embryogenesis, when normal dynein arms are missing' [17]. In 1976 he noted that the cause of situs inversus remains elusive despite many theories, but he also presciently suggested that 'cilia on the embryonic epithelia have a certain position and fixed beat direction (in normal embryos) and that their beating somehow is instrumental in determining the visceral situs' [17].

It is unclear whether Afzelius in the early years of his research was aware of experiments performed by numerous embryologists that identified the 'organizer', a group of cells necessary and sufficient to initiate a complex program of spatial organization in competent embryonic tissue (reviewed in [21]). For the groundbreaking research leading to the identification of the organizer performed by Hans Spemann (1869 to 1941) and Hilde Mangold (1898 to 1924), the Nobel Prize in Physiology or Medicine was awarded to Hans Spemann in 1935 [22]. Organizer activity was subsequently also demonstrated in embryos of higher vertebrates such as birds and mammals [23-25] in a structure that Victor Hensen (1835 to 1924) had described in 1876 in an extensive paper and named 'the node', also known as 'Hensen's node' [26].

Nearly 20 years after Afzelius expressed his hypothesis [17], scientists were just starting to put pieces of this puzzle together. It was only in 1994 that Sulik et al. published an extensive study on the development of the node and formation of the notochordal plate in embryonic day (E) 7 to 9 mice (Theiler stages 10 to 14). It is of note that Sulik et al. still found it important to define several terms such as the rostral end of the murine primitive streak will be referred to as the node (analogous to Hensen's node in avian species)' [27] because the structure was not properly assigned in previous studies $[28,29]$. It is important to note here that the 'node' in mouse was renamed several times based on morphological and functional studies. First named 'archenteron' by Theiler in 1972 [30] the term 'node' was introduced by Beddington in 1991: 'This (the archenteron) is a misnomer as it is not equivalent to the archenteron in amphibians but, as far as we can tell, corresponds to the dorsal blastopore lip of Xenopus or Hensen's node of the chick. Therefore, I would suggest that we call it the "node" [31]. Later analyses of ciliation and gene expression demonstrated in 2007 that this definition unites two entities, the node and the posterior notochord (PNC), the latter characterized by bi-lateral Nodal expression, motile monocilia and cilia-driven leftward flow and functioning as left-right (LR)-organizer. Using this functional characteristic, the PNC, still commonly named 'node' in mouse embryos, corresponds to the gastrocoel roof plate (GRP) and not to the dorsal blastopore lip of amphibians [32]. Nevertheless, in the study of Sulik et al. the authors described the presence of groupings of cells in the area of the rostral midline that had small ventral surface areas relative to adjacent cells', each with 'a prominent single, central cilium-like structure on their ventral side' at the ventral layer of the node [27]. They also performed video microscopy of the node showing that these monocilia cilia 
were motile, although they failed to find 'evidence of synchronized activity in time or direction' [27].

A year later Afzelius, who now interpreted KS as a disease caused by defective or absent cilia, presented five hypotheses to explain the 'curious' connection between ciliary defects and loss of laterality control. These hypotheses included combined loss of function of two closely linked genes, one responsible for the asymmetry of viscera and the second responsible for synthesis or assembly of ciliary structures, cytoskeletal defects [33], lack of structural coordination and defective ciliation-ordivision switch [34]. As the most likely hypothesis he suggested that 'there are cilia that have determined positions and a fixed beat direction, much the same as they have on the epidermis of amphibian embryos' [35] and that 'ciliary beating in normal embryos is assumed to be instrumental in pushing the heart to the left side, whereas chance alone will determine whether viscera will take up the normal or the reversed position during embryogenesis, when there is no regular ciliary motility' $[17,34]$. We can only speculate whether Afzelius had been aware of the study on the development of the node and formation of the notochordal plate presented by Sulik et al. [27].

\section{The nodal signaling cascade and the nodal flow}

It still took several years to gain insight into the function of cilia during the process of LR-axis development. Initially, the discovery of molecular networks acting in and around the node during patterning of the body axes constituted the major scientific breakthrough in the analysis of axis development. Although we acknowledge outstanding scientific contributions stemming from research on other model organisms, such as chicken and Хenopus, this review will focus on findings obtained in mouse studies unless otherwise stated.

In 1993, Nodal, one of the key factors of LR-axis development and a member of the transforming growth factorbeta (TGF-beta) superfamily, was identified in mice. Nodal expression was detected in a symmetric fashion exclusively at the node or 'associated with the node' dependent on the developmental stage analyzed (approximately E7 (primitive streak embryos) to E8.5 ('coinciding with the disappearance of the node as distinct structure' [36])) and named Nodal due to its localized expression at the node [36]. Surprisingly, three years later, the correlation between asymmetric gene expression and LR-asymmetry in mice became obvious in two independent studies published in Nature [37,38]. In these studies, it was demonstrated that expression of Nodal was dependent on the developmental stage and in contrast to the previously published study not only in the mouse node [36] but also in the left lateral plate mesoderm (LPM) [37,38]. In the same studies, Nodal expression was examined in mouse mutants with perturbed LR-development, especially the situs inversus viscerum (iv) displaying random LR-asymmetry [39] and the inversion of embryonic turning (inv) developing situs inversus [40]. Both mouse models were extensively used for the analysis of LR-development. It was anticipated that these mutant mice would provide important insights into the understanding of LR-development, although the genetic basis of either mutation was still unknown at that time. The authors demonstrated that Nodal expression in these mutants was either normal, reversed or bilateral depending on the morphological LRasymmetry. This was similar to previous findings in chicken [41] and Xenopus [38], thus demonstrating the evolutionary conservation of Nodal expression and suggesting that Nodal is one of the key regulators of LRdevelopment $[37,42]$. In the same volume of Nature it was shown that another gene named Lefty (left right determination factor) was transiently and asymmetrically expressed in the left LPM and the left half of the prospective floorplate during LR-axis development. Similar to Nodal expression the site of Lefty expression correlated with the morphological asymmetry observed in $i v / i v$ and inv/inv mutants [43]. Extensive studies on Lefty function surprisingly demonstrated that the original expression pattern attributed to a single Lefty gene in fact derived from two highly-related and chromosomally linked genes, Lefty-1 and Lefty-2, which were both asymmetrically expressed but with distinct expression domains functioning downstream of $i v$ and $i n v$ function [44]. In 1998, the paired-like homeodomain transcription factor 2 (PITX2) was identified in two independent studies as an additional evolutionarily conserved downstream effector of the signaling cascade that establishes asymmetries along the entire LRaxis, the Nodal signaling cascade (Figure 1) $[45,46]$.

At this time it also emerged that cilia function played a role during LR-axis development, and both the $i v$ and the inv mouse mutants were important in this respect. First described in 1956 [39], iv was mapped to mouse chromosome 12 in 1989 [47] and identified by a positional cloning approach in 1997 as an axonemal dynein heavy-chain gene named left/right-dynein ( $L r d$, currently known as dynein, axonemal, heavy chain 11; Dnah11) [48]. Lrd was shown to be expressed in the node of the embryo at E7.5, consistent with having a role in LR-development [48]. Based on the observation that the asymmetric expression patterns of Nodal and Lefty were randomized in iv/iv embryos, it was suggested that $i v$ functions early in the genetic hierarchy of LR-specification. Nevertheless, the connection between $L r d$ and cilia at the node was considered unlikely; at that time, it had been supposed that cilia at the node were immotile monocilia lacking dynein arms [49] even though ciliary motility at the node, despite no evidence of synchronized activity in time or direction, had previously been observed [27]. The gene defect underlying the LRaxis defects observed in inv mutants was identified a year 


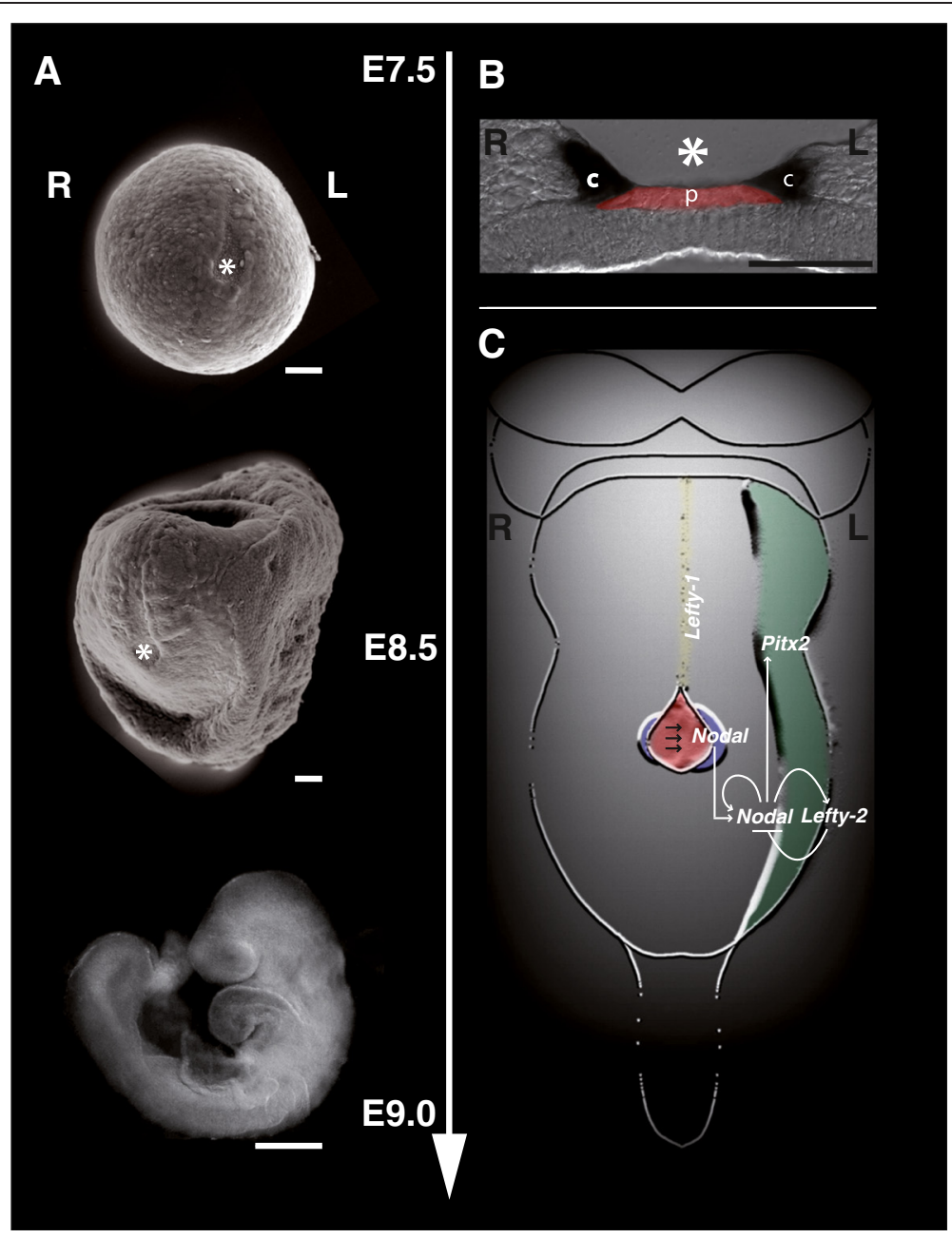

Figure 1 Timeline for laterality development (A), node structure (B) and genetic cascade of LR patterning (C) in mouse. $L R$ patterning can be divided into three steps: breakage of symmetry at the node, patterning of the LPM and asymmetric morphogenesis (A). The initial breakage of bilateral symmetry in the mouse occurs in the vicinity of the node (asterisk in $\mathbf{A}$ and $\mathbf{B}$ ) at the headfold stage corresponding to embryonic day (E)7.5 to E7.8. The node is a transient structure composed of two epithelial layers: the dorsal node and the ventral node $[27,123,124]$. The ventral node can be separated into the pit region (red in B and $\mathbf{C}$ ) and the crown region (marked by Cerl2 expression (black) in B). Pit cells carry mainly motile monocilia on their apical surface, whereas crown cells mainly carry immotile monocilia [11,118]. Motile monocilia of the node rotate in a clockwise orientation generating a leftward fluid flow over the node cavity (nodal flow; direction is marked by arrows in C). Nodal flow is sensed by cilia of the crown cells and converted into asymmetric signaling involving Nodal-Lefty1-Lefty 2 regulatory loops in the LPM and induction of Pitx2 expression in the left LPM (C). Key players of this asymmetric signaling cascade are shown with Nodal expression in crown cells (purple) and the left LPM (green), Lefty-2 and Pitx2 expression in the left LPM (green) and Lefty-1 expression in the left side of the midline (yellow) [120,123,125-130]. I and II: scanning electron micrographs of wild type mouse embryos (I: 0 somite; II: 5 somites). III: wild type mouse embryo at E9.0 viewed from the left; B: cryo section of a mouse node after in situ hybridization using a Cerl2 probe photographed using DIC optics. c: crown cells; p: pit cells; R: right; L: left. Scale bars: $50 \mu \mathrm{m}$.

later in 1998 in two independent studies. These were published five years after the first description of the inv phenotype (inversion of embryonic turning and cystic kidneys), and the gene was appropriately named Inversin [40,50,51]. Despite these findings, the function of Inversin and its connection to axis development remained unknown.

The first tangible evidence in mice that cilia of the node play an important role during LR-development came from the characterization of a mouse mutant lacking the kinesin family member 3b (KIF3B) microtubule- dependent motor protein [52] although it was not the first mouse mutant in which impaired ciliogenesis was reported [53]. Loss of Kif3b function resulted in prenatal lethality, neural tube disorganization and randomized LR-asymmetry. Lefty-2 expression was either bilateral or absent, suggesting - comparable to iv and inv mutants that Kif3b has a function upstream of the Nodal cascade. It was further shown that KIF3B was localized within the axoneme of node monocilia and that Kif3 $b$ mutant nodes lacked monocilia, suggesting that monocilia of the 
node play an important role during LR-development. To further elucidate the function of these cilia, video microscopy of the node was performed. In contrast to the then accepted understanding that these cilia lack dynein arms and appear to be immotile $[48,49]$ it was convincingly demonstrated that node monocilia were motile and capable of generating a leftward flow. Based on these data, the authors suggested that motile monocilia at the node generate a directed leftward flow leading to the concentration of a secreted factor to the left side of the node, which then triggers the downstream signaling cascade of left-defining genes, the Nodal signaling cascade, still known as the 'morphogen hypothesis' $[48,52,53]$.

Aware of the findings of Nonaka et al., Afzelius hypothesized in 1999 that exposure of embryos to highly viscous methyl cellulose during the critical stage would increase the percentage of situs inversus [54]. In fact, this hypothesis was confirmed years later using indeed methyl cellulose to influence flow in Xenopus and mouse embryos in 2007 and 2012, respectively [55,56].

The finding of nodal flow was a major scientific breakthrough with regard to the connection between cilia function and LR-axis development. Although additional mouse mutants, such as those lacking the KIF3A subunit of kinesin-II, provided supportive evidence for the relevance of cilia at the node during LR-axis development $[57,58]$, it was still necessary to eliminate the last serious doubts.

The first supporting evidence came from an extensive study showing that abnormal nodal flow precedes situs inversus in iv and inv mutant mice, demonstrating immotile cilia in $i v$ mutants lacking LRD and a slower net leftward flow in inv mutants, due to a more 'turbulent flow' despite the fact that cilia lacking Inversin rotate more rapidly [59]. These data suggested that abnormal flow is not the consequence of the abnormal LR-body axis determination but may be its source [59]. The hypothesis that the directed mechanical fluid flow across the node is implicated in the symmetry breaking event was further confirmed by elegant experiments in which wild type embryos and $i v$ mutants lacking LRD were cultured under artificial fluid flow conditions. Reversal of laterality was checked by using genetic markers at the LPM, demonstrating randomized or reversed expression previous to organ laterality development, and further confirmed by analysis of organ situs demonstrating reversal of heart looping and embryonic turning [60]. This study convincingly demonstrated that a strong rightward artificial flow could reverse fluid flow at the node and thereby the laterality of wild type embryos, proving that the laterality of treated embryos was successfully controlled by the direction of the artificial flow. Similar experiments were then performed with homozygous iv/iv mutant embryos that lack nodal flow due to immotile cilia at the node and exhibit situs inversus in half of the mutant embryos. Here, it was demonstrated that $i v / i v$ embryos responded even to slow artificial flow, manifesting normal or reversed laterality dependent on the direction of the artificial flow. Although the exact mechanism leading to the initial breakage of symmetry at the node was still unknown, these experiments unequivocally showed that efficient and directed nodal flow generated by motile monocilia at the node was necessary to establish left-right laterality in the embryo (reviewed in [61-63]).

\section{The laterality-kidney connection}

By the year 2000 more than 24 genes involved in axis development had been published, not only by analyses of existing spontaneous mouse mutations but also due to the increasing ability to genetically manipulate the mouse to generate targeted mutations (reviewed in [64]). Nevertheless, knowledge about cilia structure and function at the node was still limited.

Further insight came from a completely unexpected source, namely research performed on autosomal recessive and autosomal dominant polycystic kidney diseases (ARPKD and ADPKD, respectively). Until 1994, several spontaneous mutations in mouse lines had been described resembling ARPKD in humans, namely cpk (congenital polycystic kidneys) [65] mapped in 1991 to mouse chromosome 12 [66], bpk (BALB/c polycystic kidneys) [67], pcy (polycystic kidneys) [68] mapped in 1991 to mouse chromosome 9 [69] and jck (juvenile cystic kidneys) [70] and others (reviewed in [71]), but none of the disease-causing genes had been identified at that time, making it impossible to study the pathogenesis of PKD in more detail.

Then in 1994, a candidate gene was described to be associated with a mutation causing recessive polycystic kidney disease in mice. This gene was mutated during a large scale mutagenesis program and the line was called $\operatorname{TgN}$ (Imorpk)-737Rpw (Imorpk: insertional mutation, Oak Ridge polycystic kidneys), abbreviated TgN737Rpw and later on Oak Ridge Polycystic Kidney (orpk) insertional mutation [72,73]. The targeted allele of this mouse $\operatorname{Tg} 737$ gene, Tg737D2-3bGal, was published in 2000 [74]. Unlike the original orpk allele where all homozygotes survived to birth, embryos homozygous for the Tg737D2-3b Gal mutation arrested in development at mid-gestation and exhibited neural tube defects, enlargement of the pericardial sac and, most notably, LR-asymmetry defects with bilateral expression of Nodal and Lefty-2. It was shown that nodal monocilia were lacking, similar to the previously described Kif3b and Kif3a mutants $[52,57,58]$, providing further evidence that motile monocilia at the node are important for proper LR-axis development.

Most interesting with regard to the analysis of both $\operatorname{Tg} 737$ alleles and future analysis of ciliary function during development were the different phenotypes observed 
in these two $\operatorname{Tg} 737$ alleles: these included cystic kidneys in the hypomorphic orpk allele and a more severe phenotype involving motile monocilia at the node in the complete loss-of-function $T g 737 \mathrm{D} 2-3 \mathrm{bGal}$ allele. It was suggested that the inability to develop and maintain polarity of renal and node cells as demonstrated by lack of monocilia that were found on virtually every cell of the body [75-77] might be the underlying cause of cyst formation in the kidneys and laterality defects. This observation led to the name 'Polaris' for the gene product of $\operatorname{Tg} 737$ [74]. Further analysis demonstrated that Polaris localized just below the apical membrane in the region of the basal bodies and within cilia or flagellar axonemes [78] and that it was important for ciliogenesis of both motile and non-motile primary cilia in different model organisms [79-81], leading to the name 'Intraflagellar transport 88' (Ift88). As a result of these studies, a common key function of cilia in the development of both cystic kidneys and laterality disorders became more apparent.

At that time, based on studies performed in Caenorhabditis elegans [82,83], an association between structural and/or functional defects in primary cilia of vertebrate epithelia and another cystic kidney disease caused by mutations in PKD1 (ADPKD1) encoding polycystin-1 [84-87] and PKD2 (ADPKD2) encoding polycystin-2 [88], was suggested.

Indeed, it was possible to show that polycystin-2, next to additional polycystic kidney disease proteins, such as polycystin-1, Polaris and Cystin, localized to primary cilia of the kidney $[89,90]$ supporting this hypothesis. With regard to $P k d 2$ mouse mutants, it was previously shown that somatic inactivation of $P k d 2$ expectedly resulted in polycystic kidney disease [91] but also prenatal lethality and cardiac defects [92]. Unexpectedly, it was also shown that polycystin-2 was required for LR-axis development and that loss of $P k d 2$ function resulted in heterotaxy. Loss of Nodal, Lefty-1 and Lefty-2 expression and bilateral Pitx2 expression in $P k d 2$ mutants suggested that polycystin- 2 is active early during axis development and upstream of the Nodal signaling cascade [93]. The findings of ciliary localization of polycystin-2 in primary cilia of the kidney, LR-axis defects of $P k d 2$ mutant mouse embryos and ion channel activity of polycystin-2 [94-96] suggested that polycystin-2 might have a function in cilia of the node, perhaps as an ion channel necessary to sense and translate the leftward flow similar to the proposed function in the kidney.

\section{The two-cilia model}

Just a few months before the involvement of $P k d 2$ in laterality development was published, mutations in DNAH5 (dynein, axonemal, heavy chain 5) leading to nonfunctional DNAH5, loss of outer dynein arms and immotile cilia, were published in individuals with PCD and
KS [97] and it became increasingly likely that two different types of ciliary defects can cause laterality defects, defects in cilia motility and defects in sensory function.

The next hint came again from the kidney research field showing that polycystin- 1 and polycystin- 2 mediated mechanosensation in primary cilia of the kidney resulting in calcium influx into the cell [98]. The hypothesis was thus raised that the polycystins might have a similar function at the node.

Only a few months later it was possible to show that two populations of node monocilia initiated LR-asymmetry in the mouse. These populations could be distinguished by LRD, which localized to a motile subset of nodal monocilia, and polycystin-2, which localized to all nodal monocilia although it appeared to be enriched in non-LRD containing cilia (Figure 2) [11]. The same study showed that an asymmetric calcium signaling appeared at the left margin of the node coincident with leftward nodal flow. This signal was absent in both mutant mouse embryos lacking Lrd or $P k d 2$. These data suggested that LR-asymmetry is established by an entirely ciliary mechanism consisting of motile, LRD-containing monocilia generating the directed nodal flow and non-motile polycystin-2-containing cilia sensing the flow and initiating an asymmetric calcium signal at the left border of the node, appropriately named the 'two-cilia model' [11,99] (and reviewed in [100-103]).

\section{The polarization of nodal cells}

Nevertheless, several questions still remained with regard to ciliary function at the node: 1) how can rotational movement of node monocilia generate the unidirectional flow; 2) how can this unidirectional nodal flow be sensed by the embryo; and 3) what mechanism specifies the differentiation of the two types of cilia at the node?

A theoretical analysis of fluid dynamics at the node proposed a model in which a productive linear flow could result if the rotation axis of the cilia has a posterior tilt [104]. Careful analyses of cilia orientation and cilia movement indeed demonstrated that cilia did not stand perpendicular to the node surface but were tilted posteriorly, confirming the hypothesis postulated by the theoretical analysis $[105,106]$. That this posterior tilt was necessary to generate a directed flow and that the flow depends on the tilt angle of the cilia was further confirmed using a mechanical model simulating different scenarios [106].

However, the question remained how this posterior tilt of cilia at the node is generated. Establishment of the three body axes, anterior-posterior (AP)-, dorso-ventral (DV)- and LR-axis, is central to the vertebrate body plan. Since the LR-axis is the last axis to be determined during development, LR-polarity must be generated by utilizing the pre-existing positional cues from the AP- and DV-axes. 


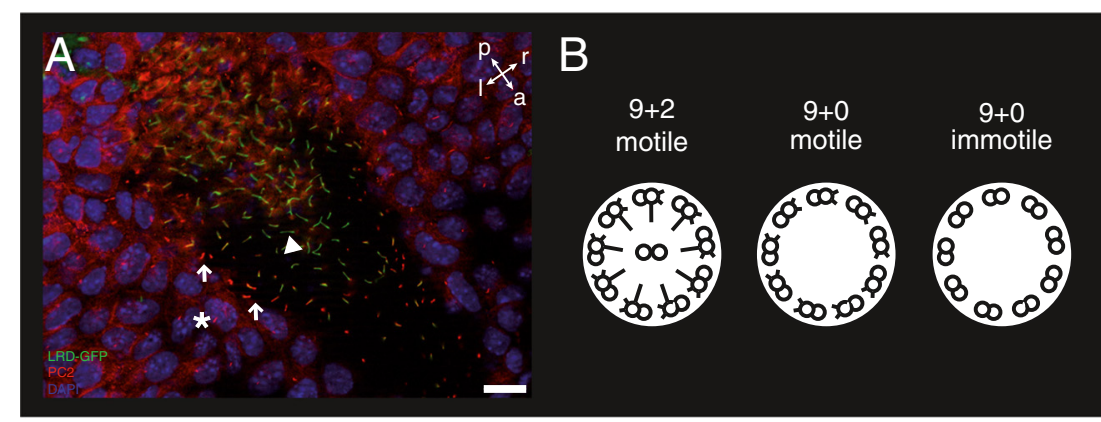

outer axonemal structures

inner axonemal structures

$\infty$ microtubule doublet

c) microtubule doublet with outer and inner dynein arms

c. microtubule doublet with outer and inner dynein arms

$\infty$ central pair complex

contral singlets with characteristic

and radial spoke

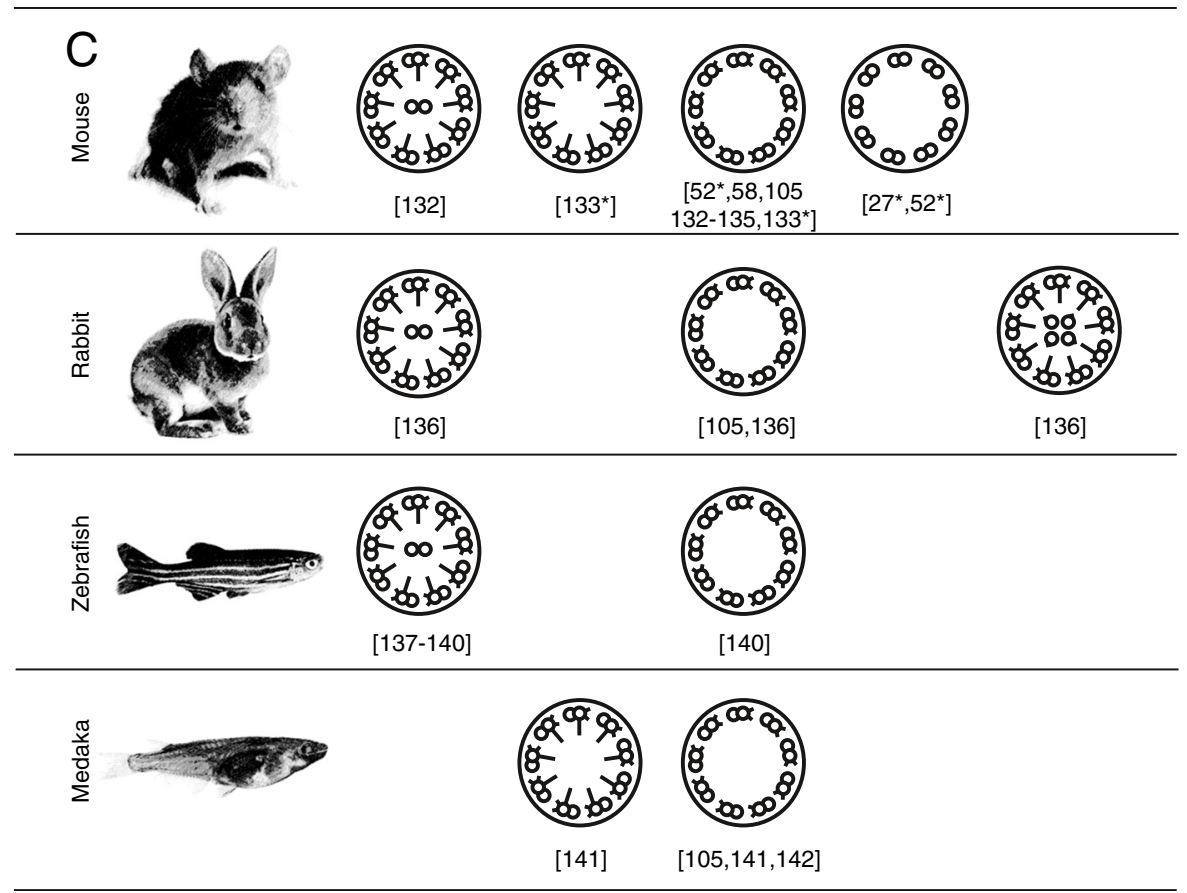

Figure 2 Types of cilia found at the left-right-organizer of vertebrates. In mouse, two types of ciliated cells at the node have been demonstrated (A). Pit cells possess motile cilia visualized by a GFP-fusion protein of DNAH11 (LRD-GFP; arrowhead). Most crown cells possess immotile cilia containing polycystin-2 but lacking LRD-GFP (arrow). It is suggested that immotile cilia of crown cells act as flow sensors. Primary cilia containing polycystin-2 are found on endodermal cells adjacent to the node (asterix). [11,101,118]. Classical motile cilia (B) possess nine outer microtubule doublets forming a ring around a central pair (CP) of single microtubules, called $9+2$ axoneme. Outer microtubule doublets possess dynein arms that drive rhythmic movement of the axonemes. Radial spoke complexes project from each outer doublet towards the CP and are thought to be important in regulating motion of the axoneme (B). Motile monocilia (B) are found in cells of the LR-organizer in various vertebrates, such as ventral node in mouse, notochordal plate in rabbit or Kupffer's vesicle in zebrafish and medaka (C). In mouse and medaka, cilia of the LR-organizer usually display the $9+0$ configuration lacking the CP. In other vertebrates, such as zebrafish, they display $9+2$ or in rabbit $9+0,9+2$ and $9+4$ configuration. Irrespective of the structure, these cilia move in a rotational manner, establishing a leftward-directed fluid flow within the cavity of the LR-organizer. Immotile cilia (B) lack motility components such as dynein arms, CP and radial spokes and act as specialized sensors of the cell transducing signals from extracellular stimuli to a cellular response [125,131]. A: Immunofluorescent staining detecting polycystin-2 (red) in node monocilia of a 2 somite stage LRD-GFP (green) mouse embryo. A: anterior; l: left; p: posterior; r: right. Scale bar: 20 ㅆm [132-142].

Previously, it had been shown that complete loss of function of Biccaudal C (BicC), the gene which is mutated in both the $b p k$ mouse model leading to an ARPKD phenotype and the $j c p k$ mouse model leading to an ADPKD phenotype $[107,108]$, resulted in LR-axis defects by disrupting the planar alignment of motile cilia required for cilia-driven fluid flow. Furthermore, it had been shown that BICC uncoupled Dishevelled 2 (DVL2) signaling from the canonical Wnt pathway, which has been implicated in antagonizing planar cell 
polarity $(\mathrm{PCP})$, the orientation of specialized structures within a plane of the epithelial sheet [109]. Thus, it was suggested that establishment of PCP is also involved in the orientation of nodal cilia.

Careful analysis of the basal body orientation demonstrated that the basal bodies of nodal cilia were initially positioned centrally. They then gradually shifted towards the posterior side of the node cells until the majority was located at the posterior side of the ciliated node cells at the two- to three-somite stage, when the velocity of the fluid flow is maximal [110]. Further analysis demonstrated that Dishevelled ( $D v l)$, a key participant of both canonical and non-canonical Wnt signaling pathways and in mice, represented by three widely expressed and functionally redundant $D v l$ genes ( $D v l 1, D v l 2$ and $D v l 3$ ), was relevant for the positioning of basal bodies, confirming this hypothesis [110].

The involvement of the canonical Wnt signaling was further excluded based on analyses performed with embryos deficient in Wnt3a, the only ligand that activates the canonical Wnt pathway in the node. These analyses demonstrated that neither the directional flow nor the rotational axis of nodal cilia and position of basal bodies were affected by loss of WNT3A, although Wnt3a mutants showed laterality defects $[110,111]$. On the other hand, blocking RAC1, a small G protein and effector molecule of the non-canonical Wnt pathway, also known as the non-canonical PCP pathway, led to defects in positioning of the basal bodies and vertical nodal flow suggesting that the non-canonical Wnt/PCP pathway is involved [110]. This hypothesis was confirmed by further analyses demonstrating that in the absence of Vangl1 and Vangl2, the two mouse homologues of the Drosophila core PCP gene Van Gogh (Vang) [112] as well as in Cofilin1;Vangl2 double mutants [113], failure to properly polarize nodal cilia led to randomization of LR-asymmetry (reviewed in [114-116]).

\section{The sensor of nodal flow}

Although mechanistic inside of how leftward nodal flow is generated progressed, exactly how this left sidespecific signal gets sensed and transduced remained enigmatic. At that time, only the Nodal inhibitor Cerl 2 had been identified to act as a critical target of flow suggesting that symmetry is broken by flow-mediated left-asymmetric release of Nodal repression at the midline [117]. Based on the mechanosensory function of polycystin-1 and polycystin-2 in kidney epithelial cells and the elevated left-side specific calcium signal at the node observed in mouse embryos, it was assumed that sensing of this flow occurs through cilia. $P k d 2$ was a good candidate since mice lacking polycstin-2 exhibited LR-patterning defects and lost the left-sided expression of Nodal, suggesting that $P k d 2$ is relevant for cilia function at the node. Interestingly, neither the structure nor the motility of nodal cilia was compromised, suggesting that loss of polycystin-2 in these cilia results in the inability to sense flow [118]. This hypothesis was confirmed by using $\mathrm{Ca}^{2+}$ signaling blockers that interfere with polycystin-2 signaling. Rescue experiments demonstrated that although endogenous polycystin-2 localized to cilia of both crown cells and pit cells of the node, the latter located at the central region of the node and mainly possessing motile cilia generating the nodal flow, polycystin- 2 was required only in crown cells for the correct establishment of LR-asymmetry. In addition, it was shown that the Nodal inhibitor Cerl2 was not only a critical target of flow but also the major target of $P k d 2$ mediated signaling during LR pattern formation. Surprisingly, it was also possible to demonstrate that restoring cilium formation in crown cells of Kif3a mutant embryos, which usually completely lack cilia, was also sufficient to induce LR-asymmetry. These data indicated that cilia of the crown cells of the node are the sensors for the leftward fluid generated at the node [118] (and reviewed in $[119,120])$.

\section{Motor or sensor?}

It was now widely accepted that laterality is initiated at the embryonic LR-organizer, where motile cilia generate leftward flow that is detected by immotile sensory cilia, which then transduce flow into downstream asymmetric signals.

In 2011, GALNT11 (N-acetylgalactosamine-type Oglycosylation enzyme) was identified as a candidate disease gene in a patient with heterotaxy [121]. Functional analyses performed in Xenopus tropicalis demonstrated that galnt11 activated Notch signaling. Live imaging of the cilia of the Xenopus organizer was also performed. These analyses demonstrated that either galnt11 or notch1 depletion increased the ratio of motile cilia at the expense of immotile cilia (producing a laterality defect reminiscent of loss of the ciliary sensor polycystin-2) and that Notch overexpression decreased this ratio (mimicking the ciliopathy PCD). These data demonstrated that galnt11-mediated notch1 signaling modulates the spatial distribution and ratio of motile and immotile cilia, deciding who is motor and who is sensor at the LR-organizer, a decision which is important for the determination of laterality [122].

\section{Conclusions}

This review attempted an historical overview of key publications and experiments that influenced the direction of research and led to our current knowledge connecting the curious link between situs inversus and ciliary abnormalities (Figure 3). Of course numerous excellent additional studies exist, which added even more details to this knowledge regarding ciliary structure and function necessary 


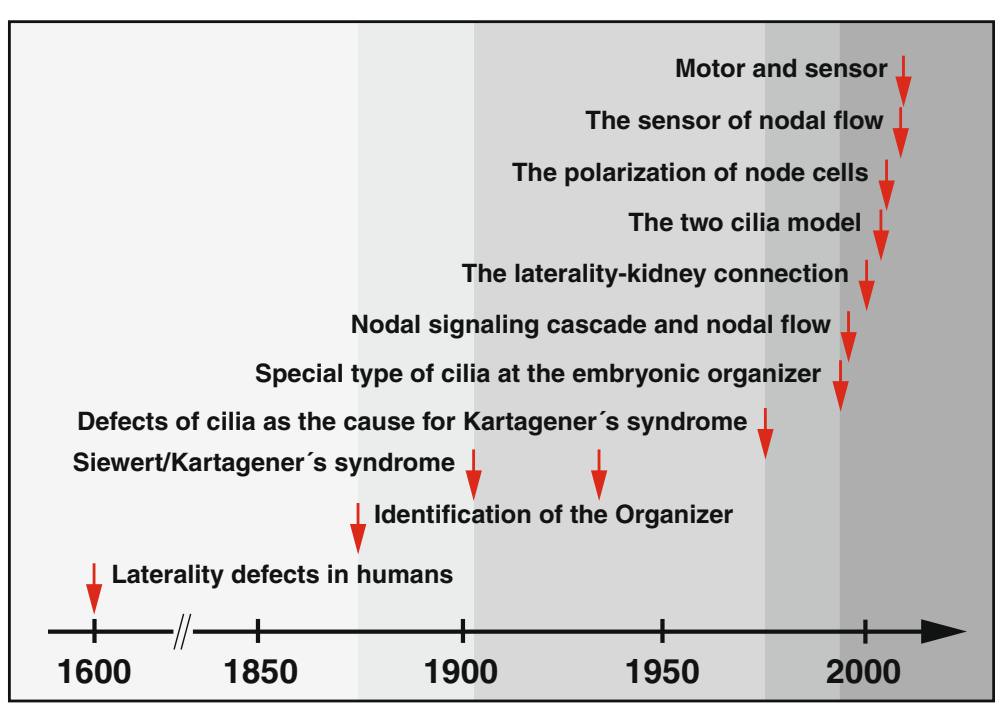

Figure 3 Milestones of research towards understanding of laterality disorders. Since the first description of laterality defects around 1600 by Fabrizio several milestones can be identified (marked with red arrows on the time scale) which led to a sharp increase in knowledge with regard to the origin of laterality defects. This included the first description of bronchiectasis in combination with situs inversus totalis by Siewert in 1904 [6] and Kartagener in 1933 [7] followed by the demonstration that ciliary defects are the underlying cause of Kartagener's syndrome in 1976 [17,18]. The demonstration of motile monocilia at the mouse node in 1994 [27] followed by the identification of the first asymmetrically expressed genes in 1996 [37,38], later known as members of the Nodal signaling cascade, opened the wide field of research on the genetic and molecular levels which led to our current knowledge about the connection of situs inversus and ciliary abnormalities. It is worth mentioning here that around the same periods, Antony van Leeuwenhoek already in 1675 described a living protozoan 'provided with diverse incredibly thin feet, or little legs, which were moved very nimbly' and that the term 'cilia' was probably first used by OF Muller in 1786 (reviewed in $[143,144]$ ).

for proper axis development. In addition, a large number of genes influencing node and ciliary structure and function have been identified. Among these, the largest group of genes influences nodal ciliogenesis (ranging from complete absence to short or abnormal cilia) (Additional file 1, Table S1). Another large group of genes influences nodal morphology and shape including orientation of cilia (PCP) necessary to generate the directed leftward flow (Additional file 1, Table S2). A third subset of genes has been shown to cause axonemal defects resulting in dyskinetic cilia and PCD (with or without heterotaxy) (Additional file 1, Table S3). Interestingly, several PCDcausing genes, to the best of our knowledge, do not cause laterality defects in either humans or mouse models but their analyses nonetheless aid to understand the structure of nodal cilia (Additional file 1, Table S4).

We can only speculate how Bjorn Afzelius, who died April 27 2008, would view the tremendous advances in molecular and genetic research that have convincingly linked ciliary function at the node to LR-axis development and, amazingly, confirmed his hypothesis from twenty years before.

We can anticipate that combined efforts by clinicians and basic researchers as well as the brisk pace of advancements in genetic analyses and modification of animal models will bring even greater understanding of how ciliary function influences LR-axis development and we are looking forward to the advancements in this field.

\section{Additional file}

Additional file 1: Table S1-S4.

\section{Abbreviations}

ADPKD: autosomal dominant polycystic kidney disease; AP: anterior-posterior; ARPKD: autosomal recessive polycystic kidney disease; BicC: Biccaudal C; Bpk: BALB/C polycystic kidneys; Cpk: Congenital polycystic kidneys;

Dnah 11: Dynein, axonemal, heavy chain 11; DNAH5: Dynein, axonemal, heavy chain 5; DV: dorso-ventral; DVl: Disheveled; E: embryonic day; GALNT11:

$\mathrm{N}$-acetylgalactosamine-type O-glycosylation enzyme; GFP: green fluorescent protein; GRP: gastrocoel roof plate; Ift88: Intraflagellar transport 88; Inv: Inversion of embryonic turning; Iv: Situs inversus viscerum; Jck: Juvenile cystic kidneys; KIF3A: Kinesin family member 3A; KIF3B: Kinesin family member 3B; KS: Kartagener's syndrome; LPM: lateral plate mesoderm; LR: leftright; Lrd: Left/right-dynein; Orpk: Oak Ridge Polycystic Kidney; PCD: primary ciliary dyskinesia; PCP: planar cell polarity; pcy: Polycystic kidneys;

Pitx2: Paired-like homeodomain transcription factor 2; PKD: polycystic kidney disease; PKD1: Polycystic kidney disease gene 1; PKD2: Polycystic kidney disease gene 2; PNC: posterior notched; RAC1: RAS-related C3 botulinum substrate 1; TGF: transforming growth factor; Vangl: Van Gogh like; Wnt: Wingless-type MMTV integration site family.

\section{Competing interests}

The authors declare that they have no competing interests.

\section{Authors' contributions}

PP and TM wrote the manuscript and designed the figures. PP, BD and $\mathrm{HH}$ revised the manuscript. All authors read and approved the final manuscript.

\section{Acknowledgements}

All studies presented here and numerous excellent studies not cited within this review for which we apologize helped us to understand a little part of laterality development, cilia structure and function and associated diseases. This gain of 
knowledge is due not least to the combined efforts of clinicians and basic researchers, the still improving methods to genetically modify and analyze model organisms for functional analysis and the brisk pace of advancements in genetic analysis. The authors thank Martina Brueckner who kindly provided Irdgfp mice. The authors thank colleagues for continuous discussions, especially Heymut Omran, Gerard W. Dougherty and Niki T. Loges. PP is funded by a research grant of the Deutsche Forschungsgemeinschaft (DFG OM 6/5), TB is funded by a research grant of the Deutsche Forschungsgemeinschaft (DFG OM 6/4), research in the lab of $\mathrm{HH}$ is funded by Core Research for Evolutional Science and Technology (CREST) of the Japan Science and Technology Corporation (JST).

\section{Author details}

'Department of General Pediatrics, University Children's Hospital Muenster, 48149 Muenster, Germany. ${ }^{2}$ Department of Human Genetics, University Hospital Muenster, 48149 Muenster, Germany. ${ }^{3}$ Graduate School of Frontier Biosciences, Osaka University, Osaka, Japan.

\section{Received: 18 August 2014 Accepted: 26 November 2014}

\section{2.}

\section{References}

1. Sutherland MJ, Ware SM (2009) Disorders of left-right asymmetry: heterotaxy and situs inversus. Am J Med Genet C Semin Med Genet 151C:307-317

2. Aylsworth AS (2001) Clinical aspects of defects in the determination of laterality. Am J Med Genet 101:345-355

3. Casey B (1998) Two rights make a wrong: human left-right malformations. Hum Mol Genet 7:1565-1571

4. Cleveland M (1926) Situs inversus viscerum: an anatomic study. Arch Surg 13(3):343-368

5. Baillie M Account of a Remarkable Transposition of the Viscera. By Matthew Baillie, M. D. In a Letter to John Hunter, Esq. F. R. S. Philos Trans Royal Soc London 78:350-363

6. Siewert A (1904) Über einen Fall von Bronchiectasie bei einem Patienten mit situs inversus viscerum. Berl Klin Wochenschr 41:139-141

7. Kartagener M (1933) Zur Pathogenese der Bronchiektasen. 1. Mitteilung: Bronchiektasien bei Situs viscerum inversus. Beitr Klin Tuberk 83:489-501

8. Rossman C, Forrest J, Newhouse M (1980) Motile cilia in "immotile cilia" syndrome. Lancet 1:1360

9. Sleigh MA (1981) Primary ciliary dyskinesia. Lancet 2:476

10. Glang E (1904) Geburtshindernis infolge von beiderseitigen Cystennieren, verbunden mit Pancreascyste und situs inversus. Universität Leipzig, Doctoral dissertation

11. McGrath J, Somlo S, Makova S, Tian X, Brueckner M (2003) Two populations of node monocilia initiate left-right asymmetry in the mouse. Cell 114:61-73

12. Afzelius B (1959) Electron microscopy of the sperm tail; results obtained with a new fixative. J Biophys Biochem Cytol 5:269-278

13. Pedersen $H$, Rebbe $H$ (1975) Absence of arms in the axoneme of immobile human spermatozoa. Biol Reprod 12:541-544

14. Afzelius BA, Eliasson R, Johnsen O, Lindholmer C (1975) Lack of dynein arms in immotile human spermatozoa. J Cell Biol 66:225-232

15. Berdon WE, McManus C, Afzelius B (2004) More on Kartagener's syndrome and the contributions of Afzelius and A.K. Siewert. Pediatr Radiol 34:585-586

16. Camner P, Mossberg B, Afzelius BA (1975) Evidence of congenitally nonfunctioning cilia in the tracheobronchial tract in two subjects. Am Rev Respir Dis 112:807-809

17. Afzelius BA (1976) A human syndrome caused by immotile cilia. Science 193:317-319

18. Pedersen $H$, Mygind N (1976) Absence of axonemal arms in nasal mucosa cilia in Kartagener's syndrome. Nature 262:494-495

19. Berdon WE, Willi U (2004) Situs inversus, bronchiectasis, and sinusitis and its relation to immotile cilia: history of the diseases and their discoverersManes Kartagener and Bjorn Afzelius. Pediatr Radiol 34:38-42

20. Rash J, Shay J, Biesele J (1969) Cilia in cardiac differentiation. J Ultrastruct Res 29:470-484

21. Viebahn C (2001) Hensen's node. Genesis 29:96-103

22. Spemann H, Mangold H (1924) Über Induktion von Embryonalanlagen durch Implantation artfremder Organisatoren. Arch mikr Anat und Entw mech 100:599-638

23. Wetzel R (1925) Undersuchungen am Huehnerkeim. 1. ueber die Untersuchungen des lebenden Keims mit neueren Methoden, besonders der
Vogtschen vitalen Farbmarkierung. Wilhelm Roux Arch Entwicklungsmech 106:463-468

24. Waddington C (1933) Induction by the primitive streak and its derivatives in the chick. J Exp Biol 10:38-46

25. Waddington C (1937) Experiments on determination in the rabbit embryo. Arch Biol 48:273-290

26. Hensen V (1876) Beobachtungen ueber die Befruchtung und Entwicklung des Kaninchens und Meerschweinchens. Z Anat Entwickl Gesch $1: 213-273$

27. Sulik K, Dehart DB, langaki T, Carson JL, Vrablic T, Gesteland K, Schoenwolf GC (1994) Morphogenesis of the murine node and notochordal plate. Dev Dyn 201:260-278

28. Poelmann R (1981) The head-process and the formation of the definitive endoderm in the mouse embryo. Anat Embryol 162:41-49

29. Jurand A (1974) Some aspects of the development of the notochord in mouse embryos. J Embryol Exp Morphol 32:1-33

30. Theiler K (1989) Stage 11 neural plate, presomite stage. In: The house mouse: atlas of embryonic development. Springer-Verlag, Heidelberg, pp 29-33

31. Beddington RS (1992) Three-dimensional representation of mouse gastrulation. In: Chadwick DJ, Marsh J (ed) CIBA Foundation Symposium 165 on Postimplantation Development in the Mouse: 3-5 June 1991 John Wiley \& Sons, London, pp 55-59

32. Blum M, Andre P, Muders K, Schweickert A, Fischer A, Bitzer E, Bogusch S, Beyer T, van Straaten HW, Viebahn C (2007) Ciliation and gene expression distinguish between node and posterior notochord in the mammalian embryo. Differentiation 75:133-146

33. Layton WM, Jr (1978) Heart malformations in mice homozygous for a gene causing situs inversus. Birth Defects Orig Artic Ser 14:277-293

34. Afzelius BA (1995) Situs inversus and ciliary abnormalities. What is the connection? Int J Dev Biol 39:839-844

35. Lofberg J (1974) Preparation of amphibian embryos for scanning electron microscopy of the functional pattern of epidermal cilia. ZOON 2:3-11

36. Zhou X, Sasaki H, Lowe L, Hogan BL, Kuehn MR (1993) Nodal is a novel TGF-beta-like gene expressed in the mouse node during gastrulation. Nature 361:543-547

37. Collignon J, Varlet I, Robertson EJ (1996) Relationship between asymmetric nodal expression and the direction of embryonic turning. Nature 381:155-158

38. Lowe LA, Supp DM, Sampath K, Yokoyama T, Wright CV, Potter SS, Overbeek P, Kuehn MR (1996) Conserved left-right asymmetry of nodal expression and alterations in murine situs inversus. Nature 381:158-161

39. Hummel K, Chapmann D (1956) Situs Viscerum Inversus. Mouse News Lett 14:21

40. Yokoyama T, Copeland NG, Jenkins NA, Montgomery CA, Elder FF, Overbeek PA (1993) Reversal of left-right asymmetry: a situs inversus mutation. Science 260:679-682

41. Levin M, Johnson RL, Stern CD, Kuehn M, Tabin C (1995) A molecular pathway determining left-right asymmetry in chick embryogenesis. Cell 82:803-814

42. Ang SL, Rossant J (1994) HNF-3 beta is essential for node and notochord formation in mouse development. Cell 78:561-574

43. Meno C, Saijoh Y, Fujii H, Ikeda M, Yokoyama T, Yokoyama M, Toyoda Y, Hamada H (1996) Left-right asymmetric expression of the TGF beta-family member lefty in mouse embryos. Nature 381:151-155

44. Meno C, Ito Y, Saijoh Y, Matsuda Y, Tashiro K, Kuhara S, Hamada H (1997) Two closely-related left-right asymmetrically expressed genes, lefty-1 and lefty-2: their distinct expression domains, chromosomal linkage and direct neutralizing activity in Xenopus embryos. Genes Cells 2:513-524

45. Ryan AK, Blumberg B, Rodriguez-Esteban C, Yonei-Tamura S, Tamura K, Tsukui T, de la Pena J, Sabbagh W, Greenwald J, Choe S, Norris DP, Robertson EJ, Evans RM, Rosenfeld MG, Izpisua Belmonte JC (1998) Pitx2 determines left-right asymmetry of internal organs in vertebrates. Nature 394:545-551

46. Yoshioka H, Meno C, Koshiba K, Sugihara M, Itoh H, Ishimaru Y, Inoue T, Ohuchi H, Semina EV, Murray JC, Hamada H, Noji S (1998) Pitx2, a bicoid-type homeobox gene, is involved in a lefty-signaling pathway in determination of left-right asymmetry. Cell 94:299-305

47. Brueckner M, D'Eustachio P, Horwich AL (1989) Linkage mapping of a mouse gene, iv, that controls left-right asymmetry of the heart and viscera. Proc Natl Acad Sci U S A 86:5035-5038

48. Supp DM, Witte DP, Potter SS, Brueckner M (1997) Mutation of an axonemal dynein affects left-right asymmetry in inversus viscerum mice. Nature 389:963-966 
49. Bellomo D, Lander A, Harragan I, Brown NA (1996) Cell proliferation in mammalian gastrulation: the ventral node and notochord are relatively quiescent. Dev Dyn 205:471-485

50. Morgan D, Turnpenny L, Goodship J, Dai W, Majumder K, Matthews L, Gardner A, Schuster G, Vien L, Harrison W, Elder FF, Penman-Splitt M, Overbeek P, Strachan T (1998) Inversin, a novel gene in the vertebrate left-right axis pathway, is partially deleted in the inv mouse. Nat Genet 20:149-156

51. Mochizuki T, Saijoh Y, Tsuchiya K, Shirayoshi Y, Takai S, Taya C, Yonekawa H, Yamada K, Nihei H, Nakatsuji N, Overbeek PA, Hamada H, Yokoyama T (1998) Cloning of inv, a gene that controls left/right asymmetry and kidney development. Nature 395:177-181

52. Nonaka S, Tanaka Y, Okada Y, Takeda S, Harada A, Kanai Y, Kido M, Hirokawa N (1998) Randomization of left-right asymmetry due to loss of nodal cilia generating leftward flow of extraembryonic fluid in mice lacking KIF3B motor protein. Cell 95:829-837

53. Chen J, Knowles HJ, Hebert JL, Hackett BP (1998) Mutation of the mouse hepatocyte nuclear factor/forkhead homologue 4 gene results in an absence of cilia and random left-right asymmetry. J Clin Invest 102:1077-1082

54. Afzelius BA (1999) Asymmetry of cilia and of mice and men. Int J Dev Biol 43:283-286

55. Schweickert A, Weber T, Beyer T, Vick P, Bogusch S, Feistel K, Blum M (2007) Cilia-driven leftward flow determines laterality in Xenopus. Curr Biol 17:60-66

56. Shinohara K, Kawasumi A, Takamatsu A, Yoshiba S, Botilde Y, Motoyama N, Reith W, Durand B, Shiratori H, Hamada H (2012) Two rotating cilia in the node cavity are sufficient to break left-right symmetry in the mouse embryo. Nat Commun 3:622

57. Marszalek JR, Ruiz-Lozano P, Roberts E, Chien KR, Goldstein LS (1999) Situs inversus and embryonic ciliary morphogenesis defects in mouse mutants lacking the KIF3A subunit of kinesin-II. Proc Natl Acad Sci U S A 96:5043-5048

58. Takeda S, Yonekawa Y, Tanaka Y, Okada Y, Nonaka S, Hirokawa N (1999) Left-right asymmetry and kinesin superfamily protein KIF3A: new insights in determination of laterality and mesoderm induction by kif3A-/- mice analysis. J Cell Biol 145:825-836

59. Okada Y, Nonaka S, Tanaka Y, Saijoh Y, Hamada H, Hirokawa N (1999) Abnormal nodal flow precedes situs inversus in iv and inv mice. Mol Cell 4:459-468

60. Nonaka S, Shiratori H, Saijoh Y, Hamada H (2002) Determination of leftright patterning of the mouse embryo by artificial nodal flow. Nature 418:96-99

61. Supp DM, Potter SS, Brueckner M (2000) Molecular motors: the driving force behind mammalian left-right development. Trends Cell Biol 10:41-45

62. Wagner MK, Yost HJ (2000) Left-right development: the roles of nodal cilia. Curr Biol 10:R149-R151

63. Brueckner M (2001) Cilia propel the embryo in the right direction. Am J Med Genet 101:339-344

64. Schneider $H$, Brueckner M (2000) Of mice and men: dissecting the genetic pathway that controls left-right asymmetry in mice and humans. Am J Med Genet 97:258-270

65. Russell E, McFarland E (1977) Cystic kindey, cy. Mouse Newslett 56:40

66. Davisson MT, Guay-Woodford LM, Harris HW, D'Eustachio P (1991) The mouse polycystic kidney disease mutation (cpk) is located on proximal chromosome 12. Genomics 9:778-781

67. Nauta J, Ozawa Y, Sweeney WE, Jr, Rutledge JC, Avner ED (1993) Renal and biliary abnormalities in a new murine model of autosomal recessive polycystic kidney disease. Pediatr Nephrol 7:163-172

68. Takahashi H, Ueyama Y, Hibino T, Kuwahara Y, Suzuki S, Hioki K, Tamaoki N (1986) A new mouse model of genetically transmitted polycystic kidney disease. J Urol 135:1280-1283

69. Takahashi H, Calvet JP, Dittemore-Hoover D, Yoshida K, Grantham JJ, Gattone VH, 2nd (1991) A hereditary model of slowly progressive polycystic kidney disease in the mouse. J Am Soc Nephrol 1:980-989

70. Atala A, Freeman MR, Mandell J, Beier DR (1993) Juvenile cystic kidneys (jck): a new mouse mutation which causes polycystic kidneys. Kidney Int 43:1081-1085

71. Schieren G, Pey R, Bach J, Hafner M, Gretz N (1996) Murine models of polycystic kidney disease. Nephrol Dial Transplant 11(Suppl 6):38-45

72. Moyer JH, Lee-Tischler MJ, Kwon HY, Schrick JJ, Avner ED, Sweeney WE, Godfrey VL, Cacheiro NL, Wilkinson JE, Woychik RP (1994) Candidate gene associated with a mutation causing recessive polycystic kidney disease in mice. Science 264:1329-1333
73. Yoder BK, Richards WG, Sweeney WE, Wilkinson JE, Avener ED, Woychik RP (1995) Insertional mutagenesis and molecular analysis of a new gene associated with polycystic kidney disease. Proc Assoc Am Physicians 107:314-323

74. Murcia NS, Richards WG, Yoder BK, Mucenski ML, Dunlap JR, Woychik RP (2000) The Oak Ridge Polycystic Kidney (orpk) disease gene is required for left-right axis determination. Development 127:2347-2355

75. Wheatley D (1995) Primary cilia in normal and pathological tissues. Pathobiology 63:222-238

76. Wheatley D, Wang A, Strugnell G (1996) Expression of primary cilia in mammalian cells. Cell Biol Int 20:73-81

77. Andrews P, Porter K (1974) A scanning electron microscopic study of the nephron. Am J Anat 140:81-115

78. Taulman PD, Haycraft CJ, Balkovetz DF, Yoder BK (2001) Polaris, a protein involved in left-right axis patterning, localizes to basal bodies and cilia. Mol Biol Cell 12:589-599

79. Pazour GJ, Dickert BL, Vucica Y, Seeley ES, Rosenbaum JL, Witman GB, Cole DG (2000) Chlamydomonas IFT88 and its mouse homologue, polycystic kidney disease gene $\operatorname{tg} 737$, are required for assembly of cilia and flagella. J Cell Biol 151:709-718

80. Qin H, Rosenbaum JL, Barr MM (2001) An autosomal recessive polycystic kidney disease gene homolog is involved in intraflagellar transport in C. elegans ciliated sensory neurons. Curr Biol 11:457-461

81. Haycraft CJ, Swoboda P, Taulman PD, Thomas JH, Yoder BK (2001) The C. elegans homolog of the murine cystic kidney disease gene Tg737 functions in a ciliogenic pathway and is disrupted in osm-5 mutant worms. Development 128:1493-1505

82. Barr MM, Sternberg PW (1999) A polycystic kidney-disease gene homologue required for male mating behaviour in C. elegans. Nature 401:386-389

83. Barr MM, DeModena J, Braun D, Nguyen CQ, Hall DH, Sternberg PW (2001) The Caenorhabditis elegans autosomal dominant polycystic kidney disease gene homologs lov-1 and pkd-2 act in the same pathway. Curr Biol 11:1341-1346

84. (1994) The polycystic kidney disease 1 gene encodes a 14 kb transcript and lies within a duplicated region on chromosome 16. The European Polycystic Kidney Disease Consortium. Cell 77:881-894

85. (1994) The polycystic kidney disease 1 gene encodes a 14 kb transcript and lies within a duplicated region on chromosome 16. The European Polycystic Kidney Disease Consortium. Cell 78:725

86. (1995) Polycystic kidney disease: the complete structure of the PKD1 gene and its protein. The International Polycystic Kidney Disease Consortium. Cell 81:289-298

87. Hughes J, Ward CJ, Peral B, Aspinwall R, Clark K, San Millan JL, Gamble V Harris PC (1995) The polycystic kidney disease 1 (PKD1) gene encodes a novel protein with multiple cell recognition domains. Nat Genet 10:151-160

88. Mochizuki T, Wu G, Hayashi T, Xenophontos SL, Veldhuisen B, Saris JJ, Reynolds DM, Cai Y, Gabow PA, Pierides A, Kimberling WJ, Breuning MH, Deltas CC, Peters DJ, Somlo S (1996) PKD2, a gene for polycystic kidney disease that encodes an integral membrane protein. Science 272:1339-1342

89. Pazour GJ, San Agustin JT, Follit JA, Rosenbaum JL, Witman GB (2002) Polycystin-2 localizes to kidney cilia and the ciliary level is elevated in orpk mice with polycystic kidney disease. Curr Biol 12:R378-R380

90. Yoder BK, Hou X, Guay-Woodford LM (2002) The polycystic kidney disease proteins, polycystin-1, polycystin-2, polaris, and cystin, are co-localized in renal cilia. J Am Soc Nephrol 13:2508-2516

91. Wu G, D'Agati V, Cai Y, Markowitz G, Park JH, Reynolds DM, Maeda Y, Le TC, Hou H, Jr, Kucherlapati R, Edelmann W, Somlo S (1998) Somatic inactivation of Pkd2 results in polycystic kidney disease. Cell 93:177-188

92. Wu G, Markowitz GS, Li L, D’Agati VD, Factor SM, Geng L, Tibara S, Tuchman J, Cai Y, Park JH, van Adelsberg J, Hou H, Jr, Kucherlapati R, Edelmann W, Somlo S (2000) Cardiac defects and renal failure in mice with targeted mutations in Pkd2. Nat Genet 24:75-78

93. Pennekamp P, Karcher C, Fischer A, Schweickert A, Skryabin B, Horst J, Blum $M$, Dworniczak B (2002) The ion channel polycystin-2 is required for left-right axis determination in mice. Curr Biol 12:938-943

94. Hanaoka K, Qian F, Boletta A, Bhunia AK, Piontek K, Tsiokas L, Sukhatme VP, Guggino WB, Germino GG (2000) Co-assembly of polycystin-1 and -2 produces unique cation-permeable currents. Nature 408:990-994

95. Gonzalez-Perrett S, Kim K, Ibarra C, Damiano AE, Zotta E, Batelli M, Harris PC, Reisin IL, Arnaout MA, Cantiello HF (2001) Polycystin-2, the protein mutated in autosomal dominant polycystic kidney disease (ADPKD), is a Ca2 + -permeable nonselective cation channel. Proc Natl Acad Sci U S A 98:1182-1187 
96. Koulen P, Cai Y, Geng L, Maeda Y, Nishimura S, Witzgall R, Ehrlich BE, Somlo S (2002) Polycystin-2 is an intracellular calcium release channel. Nat Cell Biol 4:191-197

97. Olbrich H, Haffner K, Kispert A, Volkel A, Volz A, Sasmaz G, Reinhardt R, Hennig S, Lehrach H, Konietzko N, Zariwala M, Noone PG, Knowles M, Mitchison HM, Meeks M, Chung EM, Hildebrandt F, Sudbrak R, Omran H (2002) Mutations in DNAH5 cause primary ciliary dyskinesia and randomization of left-right asymmetry. Nat Genet 30:143-144

98. Nauli SM, Alenghat FJ, Luo Y, Williams E, Vassilev P, Li X, Elia AE, Lu W, Brown EM, Quinn SJ, Ingber DE, Zhou J (2003) Polycystins 1 and 2 mediate mechanosensation in the primary cilium of kidney cells. Nat Genet 33:129-137

99. Tabin CJ, Vogan KJ (2003) A two-cilia model for vertebrate left-right axis specification. Genes Dev 17:1-6

100. McGrath J, Brueckner M (2003) Cilia are at the heart of vertebrate left-right asymmetry. Curr Opin Genet Dev 13:385-392

101. Nauli SM, Zhou J (2004) Polycystins and mechanosensation in renal and nodal cilia. Bioessays 26:844-856

102. Yost HJ (2003) Left-right asymmetry: nodal cilia make and catch a wave. Curr Biol 13:R808-R809

103. Basu B, Brueckner M (2008) Cilia multifunctional organelles at the center of vertebrate left-right asymmetry. Curr Top Dev Biol 85:151-174

104. Cartwright JH, Piro O, Tuval I (2004) Fluid-dynamical basis of the embryonic development of left-right asymmetry in vertebrates. Proc Natl Acad Sci U S A 101:7234-7239

105. Okada Y, Takeda S, Tanaka Y, Izpisua Belmonte JC, Hirokawa N (2005) Mechanism of nodal flow: a conserved symmetry breaking event in leftright axis determination. Cell 121:633-644

106. Nonaka S, Yoshiba S, Watanabe D, Ikeuchi S, Goto T, Marshall WF, Hamada $H$ (2005) De novo formation of left-right asymmetry by posterior tilt of nodal cilia. PLoS Biol 3:e268

107. Guay-Woodford LM, Bryda EC, Christine B, Lindsey JR, Collier WR, Avner ED, D'Eustachio P, Flaherty L (1996) Evidence that two phenotypically distinct mouse PKD mutations, bpk and jcpk, are allelic. Kidney Int 50:1158-1165

108. Cogswell C, Price SJ, Hou X, Guay-Woodford LM, Flaherty L, Bryda EC (2003) Positional cloning of jcpk/bpk locus of the mouse. Mamm Genome 14:242-249

109. Maisonneuve C, Guilleret I, Vick P, Weber T, Andre P, Beyer T, Blum M, Constam DB (2009) Bicaudal C, a novel regulator of Dvl signaling abutting RNA-processing bodies, controls cilia orientation and leftward flow. Development 136:3019-3030

110. Hashimoto M, Shinohara K, Wang J, Ikeuchi S, Yoshiba S, Meno C, Nonaka S, Takada S, Hatta K, Wynshaw-Boris A, Hamada H (2010) Planar polarization of node cells determines the rotational axis of node cilia. Nat Cell Biol 12:170-176

111. Nakaya MA, Biris K, Tsukiyama T, Jaime S, Rawls JA, Yamaguchi TP (2005) Wnt3a links left-right determination with segmentation and anteroposterior axis elongation. Development 132:5425-5436

112. Song H, Hu J, Chen W, Elliott G, Andre P, Gao B, Yang Y (2010) Planar cell polarity breaks bilateral symmetry by controlling ciliary positioning. Nature 466:378-382

113. Mahaffey JP, Grego-Bessa J, Liem KF, Jr, Anderson KV (2013) Cofilin and Vangl2 cooperate in the initiation of planar cell polarity in the mouse embryo. Development 140:1262-1271

114. Wallingford JB (2010) Planar cell polarity signaling, cilia and polarized ciliary beating. Curr Opin Cell Biol 22:597-604

115. Hashimoto M, Hamada H (2010) Translation of anterior-posterior polarity into left-right polarity in the mouse embryo. Curr Opin Genet Dev 20:433-437

116. Farnum CE, Wilsman NJ (2011) Axonemal positioning and orientation in three-dimensional space for primary cilia: what is known, what is assumed, and what needs clarification. Dev Dyn 240:2405-2431

117. Schweickert A, Vick P, Getwan M, Weber T, Schneider I, Eberhardt M, Beyer T, Pachur A, Blum M (2010) The nodal inhibitor Coco is a critical target of leftward flow in Xenopus. Curr Biol 20:738-743

118. Yoshiba S, Shiratori H, Kuo IY, Kawasumi A, Shinohara K, Nonaka S, Asai Y, Sasaki G, Belo JA, Sasaki H, Nakai J, Dworniczak B, Ehrlich BE, Pennekamp P Hamada H (2012) Cilia at the node of mouse embryos sense fluid flow for left-right determination via Pkd2. Science 338:226-231

119. Babu D, Roy S (2013) Left-right asymmetry: cilia stir up new surprises in the node. Open Biol 3:130052

120. Yoshiba S, Hamada H (2014) Roles of cilia, fluid flow, and Ca2+ signaling in breaking of left-right symmetry. Trends Genet 30:10-17

121. Fakhro KA, Choi M, Ware SM, Belmont JW, Towbin JA, Lifton RP, Khokha MK, Brueckner M (2011) Rare copy number variations in congenital heart disease patients identify unique genes in left-right patterning. Proc Natl Acad Sci U S A 108:2915-2920
122. Boskovski MT, Yuan S, Pedersen NB, Goth CK, Makova S, Clausen H, Brueckner M, Khokha MK (2013) The heterotaxy gene GALNT11 glycosylates Notch to orchestrate cilia type and laterality. Nature 504:456-459

123. Shiratori $H$, Hamada $H$ (2006) The left-right axis in the mouse: from origin to morphology. Development 133:2095-2104

124. Lee JD, Anderson KV (2008) Morphogenesis of the node and notochord: the cellular basis for the establishment and maintenance of left-right asymmetry in the mouse. Dev Dyn 237:3464-3476

125. Fliegauf M, Benzing T, Omran H (2007) When cilia go bad: cilia defects and ciliopathies. Nat Rev Mol Cell Biol 8:880-893

126. Komatsu Y, Mishina Y (2013) Establishment of left-right asymmetry in vertebrate development: the node in mouse embryos. Cell Mol Life Sci 70:4659-4666

127. Nakamura T, Hamada H (2012) Left-right patterning: conserved and divergent mechanisms. Development 139:3257-3262

128. Saijoh Y, Viotti M, Hadjantonakis AK (2014) Follow your gut: relaying information from the site of left-right symmetry breaking in the mouse. Genesis 52:503-514

129. Shiratori $H$, Hamada H (2014) TGFbeta signaling in establishing left-right asymmetry. Semin Cell Dev Biol 32C:80-84

130. Choksi SP, Lauter G, Swoboda P, Roy S (2014) Switching on cilia: transcriptional networks regulating ciliogenesis. Development 141:1427-1441

131. Ibanez-Tallon I, Heintz N, Omran H (2003) To beat or not to beat: roles of cilia in development and disease. Hum Mol Genet 12 Spec No 1:R27-R35

132. Caspary T, Larkins CE, Anderson KV (2007) The graded response to Sonic Hedgehog depends on cilia architecture. Dev Cell 12:767-778

133. Alten L, Schuster-Gossler K, Beckers A, Groos S, Ulmer B, Hegermann J, Ochs M, Gossler A (2012) Differential regulation of node formation, nodal ciliogenesis and cilia positioning by Noto and Foxj1. Development 139:1276-1284

134. Beckers A, Alten L, Viebahn C, Andre P, Gossler A (2007) The mouse homeobox gene Noto regulates node morphogenesis, notochordal ciliogenesis, and left right patterning. Proc Natl Acad Sci U S A 104:15765-15770

135. Kinzel D, Boldt K, Davis EE, Burtscher I, Trumbach D, Diplas B, Attie-Bitach T, Wurst W, Katsanis N, Ueffing M, Lickert H (2010) Pitchfork regulates primary cilia disassembly and left-right asymmetry. Dev Cell 19:66-77

136. Feistel K, Blum M (2006) Three types of cilia including a novel $9+4$ axoneme on the notochordal plate of the rabbit embryo. Dev Dyn 235:3348-3358

137. Kramer-Zucker AG, Olale F, Haycraft CJ, Yoder BK, Schier AF, Drummond IA (2005) Cilia-driven fluid flow in the zebrafish pronephros, brain and Kupffer's vesicle is required for normal organogenesis. Development 132:1907-1921

138. Kreiling JA, Prabhat WG, Creton R (2007) Analysis of Kupffer's vesicle in zebrafish embryos using a cave automated virtual environment. Dev Dyn 236:1963-1969

139. Wilson CW, Nguyen CT, Chen MH, Yang JH, Gacayan R, Huang J, Chen JN, Chuang PT (2009) Fused has evolved divergent roles in vertebrate Hedgehog signalling and motile ciliogenesis. Nature 459:98-102

140. Ferrante MI, Romio L, Castro S, Collins JE, Goulding DA, Stemple DL, Woolf AS, Wilson SW (2009) Convergent extension movements and ciliary function are mediated by ofd1, a zebrafish orthologue of the human oral-facial-digital type 1 syndrome gene. Hum Mol Genet 18:289-303

141. Omran H, Kobayashi D, Olbrich H, Tsukahara T, Loges NT, Hagiwara H, Zhang Q, Leblond G, OToole E, Hara C, Mizuno H, Kawano H, Fliegauf M, Yagi T, Koshida S, Miyawaki A, Zentgraf $H$, Seithe $H$, Reinhardt R, Watanabe $Y$, Kamiya R, Mitchell DR, Takeda H (2008) Ktu/PF13 is required for cytoplasmic pre-assembly of axonemal dyneins. Nature 456:611-616

142. Kobayashi D, lijima N, Hagiwara H, Kamura K, Takeda H, Yokoyama T (2010) Characterization of the medaka (Oryzias latipes) primary ciliary dyskinesia mutant, jaodori: redundant and distinct roles of dynein axonemal intermediate chain 2 (dnai2) in motile cilia. Dev Biol 347:62-70

143. Satir P (1995) Landmarks in cilia research from Leeuwenhoek to us. Cell Motil Cytoskeleton 32(2):90-94, Erratum in: Cell Motil Cytoskeleton 1999:42(1):82

144. Bloodgood RA (2009) From central to rudimentary to primary: the history of an underappreciated organelle whose time has come. The primary cilium. Methods Cell Biol 94:3-52 